\title{
Protecting the Mediterranean: Ottoman Responses to Maritime Violence, 1718-1770
}

\author{
Michael Talbot \\ University of Greenwich \\ m.h.talbot@gre.ac.uk
}

\begin{abstract}
This article examines the evolving role of the Ottoman navy in the mid-eighteenth century in protecting Ottoman seas from maritime violence. Despite enjoying a general peace with its European neighbors, merchant shipping in the waters of the eastern Mediterranean and coastal settlements were frequently subject to seaborne violence from European privateers, Maltese corsairs, and domestic pirates. Based on extensive research in the Ottoman archives, this article analyzes the development of the policy of protection (muhāfazaa) through defensive naval patrols, which occurred in conjunction with a strengthening of coastal fortifications and the implementation of innovative legal measures. The aims of this protective policy were to protect domestic and international trade, and to demonstrate imperial authority in Ottoman waters both in response to a demand for protection from subjects in the provinces from local and foreign violence, and as part of strengthening and consolidating Ottoman maritime territoriality in the Mediterranean.
\end{abstract}

\section{Keywords}

Mediterranean - Ottoman Empire - maritime territoriality - maritime space piracy maritime violence

I would like to express my gratitude to Colin Heywood, Chris Ware, Emrah Safa Gürkan, Sotirios Dimitriadis, and Antonis Hadjikyriacou for their invaluable comments, critiques, and suggestions on earlier drafts of this paper. I should also like to thank the anonymous reviewers, whose reports helped to shape this paper into something rather more polished than when it first arrived on their desks. 


\section{Introduction}

In January 1748, a ceremony was held marking the relaunch of the flagship Nașr-ı Bahrī (Victory of the Sea) after major repairs in the Istanbul dockyards. ${ }^{1}$ Destined for the Mediterranean, its mission was to protect seas in great turmoil, with British privateers assaulting French shipping in the waters around Crete and Syria resulting in huge losses for Ottoman merchants freighting their goods, whilst Maltese corsairs and Maniot pirates were raiding coastal settlements and islands, stealing produce and enslaving the inhabitants. The Ottoman reaction was, in part through the use of ships like the Nașr-ı Bahrī, to ensure Bahr-ı Sefid muhäfazası, the protection of the Mediterranean. Given the impossibility of physically imposing permanent territorial claims over liquid territory, the Ottoman state bolstered regular naval patrols alongside improved coastal fortifications and new legal practices to ensure peace and security in its waters. This required a significant investment in manpower, provisions, and armaments, as well as cooperation with the provincial authorities. The Mediterranean Sea was therefore a space of intense imperial interest and immense territorial importance in the mid-eighteenth century.

The Ottoman Mediterranean has also been a space of increasing historiographical importance. In a number of ways, histories of the Ottoman Mediterranean still live with the legacy of Fernand Braudel's La Méditerranée et le monde méditerranéen à l'époque de Philippe II, particularly his idea of l'intrusion nordique - the Northern Invasion - that marked a period of growing northern European political and economic domination from the seventeenth century at the expense of the Mediterranean powers, including the Ottomans. ${ }^{2}$ The Braudelian paradigm of examining the Mediterranean as a unit was further developed in Faruk Tabak's The Waning of the Mediterranean, 1550-1870, a significant piece of scholarship that brought a vast Mediterranean history onto an even wider global scale, which nonetheless saw the seventeenth and eighteenth centuries as a period of decline. ${ }^{3}$ It is the continuing connectivity and interculturality of the Mediterranean, not least the eastern part, that has seen Braudel's assessment of the seventeenth century subject to varying

1 Başbakanlık Osmanlı Arşivleri (Prime Ministry's Ottoman Archives, Istanbul, BOA), Cevdet Tasnifi, Bahriye (Cevdet Series, Naval, C.BH.) 146/6983 (19 Şaban 116o / 26 August 1747); C.BH.76/3647 (20 Muharrem 1161/ 3 January 1748).

2 Fernand Braudel, La Méditerranée et le monde méditerranéen à l'époque de Philippe II (Paris, 1982), vol. 1, esp. 578-580.

3 Faruk Tabak, The Waning of the Mediterranean, 1550-1870: A Geohistorical Approach (Baltimore, 2008), esp. 165-185, 210-216. 
degrees of reassessment and development in recent decades through specific case-studies, from Molly Greene's studies on the changing nature of corsairing to Daniel Panzac on la caravane maritime that demonstrated the growing role of European freighters in Ottoman commerce in the seventeenth and eighteenth centuries. ${ }^{4}$ The legacy of this Northern Invasion continues into the eighteenth century, a period treated somewhat unevenly either in terms of a legacy of the seismic shifts of the seventeenth or a presage of even more profound changes in the nineteenth. ${ }^{5}$ Another sort of approach to this period, beyond Braudel or Tabak's economic and climatic longue durées has been suggested by Colin Heywood, with microhistories of individual stories and incidents enabling a prosopographic approach to provide a human balance to the great economic narratives. ${ }^{6}$ The answer, as Maria Fusaro suggests, is to combine such histories of the Mediterranean with histories in the Mediterranean. ${ }^{7}$ When thinking about the Ottoman Mediterranean in context of wider developments, and with individual cases from the historical record being examined, what marks the eighteenth century as different is a new form of Northern Invasion with the presence of European privateers in the Eastern

4 For an important overview of Braudel's legacy, see: Maria Fusaro, "After Braudel: A reassessment of Mediterranean history between the Northern Invasion and the caravane maritime" in Trade and Cultural Exchange in the Early Modern Mediterranean: Braudel's Maritime Legacy, ed. Maria Fusaro, Colin Heywood and Mohamed-Salah Omri (London/New York, 2010), 1-22. Molly Greene, "Beyond the Northern Invasion: The Mediterranean in the Seventeenth Century," Past \& Present 174 (2002): 42-71; Molly Greene, “'Victims of piracy?': Ottoman lawsuits in Malta (1602-1687) and the changing course of Mediterranean maritime history" in Trade and Cultural Exchange, ed. Fusaro et al, 177-202; Daniel Panzac, "International and Domestic Maritime Trade in the Ottoman Empire during the Eighteenth Century," International Journal of Middle East Studies 24 (1992): 189-206; Daniel Panzac, La caravane maritime: Marins européens et marchands ottomans en Méditerranée, 1680-1830 (Paris, 2004); Daniel Panzac, "Plague and seafaring in the Ottoman Mediterranean in the eighteenth century," in Trade and Cultural Exchange, ed. Fusaro et al, 45-68.

5 Molly Greene, "The Ottomans in the Mediterranean" in The Early Modern Ottomans: Remapping the Empire, ed. Virginia Aksan and Daniel Goffman (Cambridge, 2007), 61-74; Daniel Panzac, "La géostratégie navale de l'Empire ottomane (des origines à l'apparition du cuirassé)" in Mutazioni e permanenze nella sotria navale del Mediterraneo secc. XVI-XIX, ed. Guido Candiani and Lucca Lo Basso (Milan, 2010); 103-110. Tuncay Zorlu, Innovation and Empire in Turkey: Sultan Selim III and the Modernisation of the Ottoman Nary (London/New York, 2008).

6 Colin Heywood, "The English in the Mediterranean, 1600-1630: A post-Braudelian perspective on the 'Northern Invasion'," in Trade and Cultural Exchange, ed. Fusaro et al., 23-44, esp. 23-31.

7 Fusaro, "After Braudel," 2-4. 
Mediterranean, resulting in new Ottoman legal and strengthened naval responses to the violence they committed. ${ }^{8}$

The extent of the ability of the Ottomans to respond to maritime violence has been the subject of some discussion, with Edhem Eldem arguing that they were forced to abandon its seas to pirates, domestic and foreign, and foreign naval forces by the second half of the eighteenth century. ${ }^{9}$ By contrast, Yusuf Alperen Aydın has demonstrated that the Ottoman state in the Aegean used a variety of strategies, from fortification building to naval patrols, to defend those waters, emphasizing the great expense that these measures brought upon the imperial treasury. ${ }^{10}$ These two studies have delineated the eighteenth-century Ottoman Mediterranean as a contested space by presenting two opposing conclusions, with the first emphasizing a timid retreat of an outdated Ottoman fleet to the safety of coastal waters in part in response to encroaching Europeans, and the second a huge but financially crippling project of investment in naval and coastal countermeasures with some limited success.

The questions raised by these studies are crucial in giving the eighteenth century a more considered place in Ottoman history, particularly in terms of questions of military strength and foreign relations. Military weaknesses and failures in particular have played a role in propping up the widely-discredited "decline" narrative, and the history of the Ottoman navy has been crucial to this, first (as the story goes) with the defeat at Lepanto in 1571, then a general technological decline leading to European supremacy by the start of the eighteenth century during which a terminal rot set in, evidenced by disaster at the Battle of Çeşme in 1770, and followed in the nineteenth century by inevitable collapse witnessed by defeats to the Greeks at Gerontas (1824); to a British, French, and Russian fleet at Navarino (1827); and at Sinop to the Russians (1853). ${ }^{11}$ Focus on these defeats has lost sight of Ottoman attitudes to

8 Edhem Eldem, "Strangers in their own seas? The Ottomans in the eastern Mediterranean basin in the second half of the eighteenth century," Studi Settencenteschi 29-30 (2010): 25-58; Michael Talbot, "Ottoman seas and British privateers: Defining maritime territoriality in the eighteenth-century Levant" in Well-Connected Domains: Towards an Entangled Ottoman History (Leiden, 2014), 54-70.

9 Eldem, "Strangers," 52.

10 Yusuf Alperen Aydın, 18. Yüzyılda Osmanlı Devleti'nin Ege (Adalar) Denizi ve Doğu Akdeniz'e Yönelik Güvenlik Parametreleri', Osmanlı Araştırmaları / The Journal of Ottoman Studies 45 (2015): 161-184.

11 On the sea specifically, see: Palmira Brummett, "The Ottomans as a World Power: What We Don't Know about Ottoman Sea-Power," Oriente Moderno 20 (2001): 1-21. More generally: Dana Sajdi, "Decline, its Discontents and Ottoman Cultural History: By way of Introduction" in Dana Sajdi, ed., Ottoman Tulips, Ottoman Coffee (London/New York, 
the Mediterranean in the eighteenth century in particular, which centered on defining and defending territorial waters. Just as Palmira Brummett's seminal study on the sixteenth-century maritime setting placed the Ottomans within a wider entangled commercial and political sphere in its own right beyond simplifications of an "Islamic" or "military" state to be undone by the European colonial project, I hope here to show that in this crucial period of the middle decades of the eighteenth century, often overlooked in the historiography in part because of those later naval defeats, the Ottoman state was active in developing legal and naval strategies aimed at protecting its commercial and political position in the Mediterranean. ${ }^{12}$ As such, the Ottoman navy did more than simply guard merchant ships and fight pirates in the eighteenth century; protection was part of territoriality. ${ }^{13}$ More importantly, I hope to challenge the idea that the Ottoman Empire ceased responding to threats to its maritime sovereignty in the second half of the eighteenth century, and that the open sea, however that may be defined, became off-limits to them. ${ }^{14}$ Rather, through continuing naval patrols and new legal measures, the eighteenth century was a key moment in the Ottoman attempt, however unsuccessful, to protect its maritime and littoral subjects and interests.

This paper is based on an extensive analysis of a significant body of hundreds of Ottoman archival documents from the administrative records of the Ottoman state relating to the navy in the Prime Ministry's Ottoman Archives in Istanbul (Başbakanlık Osmanlı Arşivleri) from the late seventeenth to late eighteenth centuries, primarily financial records relating to provisioning and salaries, commands to admirals and correspondence with the provinces, petitions, and official memoranda, all examined for ideas of muhăa $f a z a$ - a term meaning protection, defense, or guarding — with regard to the Mediterranean..$^{15}$

2014), 1-40; Jonathan Grant, "Rethinking the Ottoman Decline: Military Technology Diffusion in the Ottoman Empire, Fifteenth to Eighteenth Centuries," Journal of World History 10 (1999): 179-201.

12 Palmira Brummett, Ottoman Seapower and Levantine Diplomacy in the Age of Discovery (Albany, 1994), 3-5, 134.

13 Aydın, "Güvenlik Parametreleri," 161.

14 Eldem, "Strangers," 52.

15 The term muhāfaza also has an administrative connotation, with a muhāfiz being a commander responsible for the protection of a province or city. The records of the Ottoman state to which I refer are a mixture of narrative, discursive, and financial papers, and often with features of all three on one document. Primarily taken from the archival series organized by the Ottoman historians Ahmed Cevdet Paşa (1822-1895), Ali Emiri (1857-1924), and İbnülemin Mahmud Kemal (İnal) (1870-1957), they show the workings of the Ottoman administration, and those on the navy have links with a variety of departments of state. 
A number of the examples cited here are exceptional cases that represent a shift in attitudes or a particularly illustrative case, but most are picked as representative documents from this large tranche of often formulaic financial and administrative records. By considering them as a whole, examining changes and developments over several decades, I have attempted to reconstruct these Ottoman efforts to assert their authority in their Mediterranean waters, and to assess the development of muhäfaza as a distinctive policy of maritime protection. In tracing the growing investment in naval patrols between the Treaty of Passarowitz of 1718 and the Battle of Çeşme of 1770, together with new legal measures aimed at halting foreign violence, this article will show that the Ottoman state was not a passive observer of violence in its Mediterranean waters, taking extensive and expensive - if not always successful—actions to ensure the freedom of movement of merchant ships and the safety of its littoral subjects. ${ }^{16}$

In reacting to the complaints of Ottoman officials and subjects throughout the Mediterranean, three major approaches were taken by the Ottoman state. The first was the strengthening of coastal defenses by building new fortifications and repairing old ones, and reinforcing and enlarging garrisons where necessary. ${ }^{17}$ The second, specifically as a measure to halt attacks by müste'min privateers - that is, the privateers of states in treaty with the Ottoman Empire-was to institute a new legal space across the Mediterranean during the European wars within which all acts of violence were liable to prosecution, referred to by the Ottomans as şurūte $u$ derya and by the British as the maritime regulations. ${ }^{18}$ The third was the development of muhäafaza (protection) missions, which had their roots in corsairing voyages (korsanlı) where a set number of ships would cruise (geşt ve güzār etmek) in certain regions

For instance, the documents detailing expenditure on naval provisions for a protection mission contain a petition for the provisions, a summary of the case with requests for direction, queries and endorsements by senior officials from a number of departments, and calculations and receipts written in the distinctive siyakat accounting script by the state clerks.

16 On maritime space, see: Colin Heywood, "Ottoman territoriality versus maritime usage: The Ottoman islands and English privateering in the wars with France, 1689-1714" in Insularités ottomanes, ed. Nicolas Vatin and Gilles Veinstein (Paris, 2004), 145-173, and "A Frontier Without Archaeology? The Ottoman Maritime Frontier in the Western Mediterranean, $1660-1760 "$ in The Frontiers of the Ottoman World, ed. A.C.S. Peacock (London, 2009), 493-508.

17 Annon Cohen, "Ottoman rule and the re-emergence of the coast of Palestine," Revue de l'Occident musulman et de la Médierannée 39 (1995): 163-175.

18 Talbot, "Ottoman seas." 
of the Mediterranean to act as a deterrent and as visible sign of Ottoman authority in claimed territorial waters (sular). Initially a response to the risk of incursions by enemy fleets, a steady build-up of piracy and corsairing in the eastern Mediterranean in the 1730 s led to the bolstering of regular naval patrols along the coasts and in the open seas. By the 1760 s, these patrols were not reactive but institutionalized as seasonal missions. Whether the threat came from a Morean pirate, a Maltese corsair, or a British privateer, the problem required the regular presence of the imperial fleet in the Mediterranean to act as a deterrent and, where necessary, to apprehend or destroy hostile ships. As well as representing a specific response to the threats posed to Ottoman commerce, international trade, and the safety of Ottoman subjects living in coastal settlements, and to the requests for help from Ottoman officials, merchants, and coastal subjects in the provinces, the material and legal dimensions of muhăa $a z a$ gave the Ottoman state the opportunity to enforce claims over maritime territory.

\section{Territoriality, Piracy, and Muḥäfaza, 1718-1739}

The defining theme of the period under examination is the growing presence of European privateers, along with existing corsairs and domestic pirates, at a time of political and diplomatic transition and occasional economic hardship, all of which drove the Ottoman state to build regular naval patrols to secure its maritime territory, trade and shipping routes, and to protect its subjects in conjunction with extraordinary legal measures. However, the dates used to mark this study are not fixed chronological boundaries, but mark a convergence of two key developments in the enhanced use of naval patrols to protect coastal areas and maritime trade routes, and the implementation of new legal practices aimed at preventing violence in Ottoman waters during the European wars, both part of a legacy of a heightened sense of territoriality, maritime or otherwise, after the negotiated peace settlements of the late seventeenth and early eighteenth centuries. This is also a period referred to in one study as a time of pax Ottomana, with no major fleet engagements in the Mediterranean between the Ottomans and their major enemies between the battles with Venice in the summer of 1717 and those with the Russians in the summer of $1770 .{ }^{19}$ However, this period of supposed peace was marked by

19 Daniel Panzac, "Osmanlı Donanması: Başlangıçdan Nizâm-ı Cedid'e Kadar (14-18 Yüzyllar)” in Osmanlı Donanmasının Seyir Defteri: Gemiler, Efsaneler, Denizciler, ed. Ekrem Işın (Istanbul, 2009), 16-31 at 28. 
increasing attempts to define and manage frontiers in both the Mediterranean and the Adriatic in legal and naval terms following the conflicts and treaties of the late seventeenth and early eighteenth centuries. ${ }^{20}$

The Ottoman-Venetian/Habsburg war that began in 1714 was concluded by the Treaty of Passarowitz in 1718, a treaty that focused strongly on the delineation and confirmation of sovereign space. In the preceding two decades, there had been a fundamental shift in the relations between the Ottoman Empire and its western neighbors, a major constituent of which had been the formal setting of demarcated borders, first in the Treaty of Carlowitz in 1699, and then in Passarowitz, leading to new ideas of fixed spaces that marked Ottoman versus non-Ottoman. ${ }^{21}$ On land, there were border commissions, inspections, and landmarks to ensure that space was clearly defined. At sea, however, things were rather different. The idea that the Ottoman state could demarcate and enforce its law upon an abstract space had arisen in part in reaction to the violence perpetrated by British and French privateers in and around Ottoman ports and coastal waters during the Nine Years' War (16881697). ${ }^{22}$ In 1696, the Ottomans had instituted maritime regulations intended to make the entire Aegean out of bounds to foreign fighting vessels in order to protect Ottoman subjects, ports, and waters, with a line drawn across the Aegean beyond which violence was forbidden and compensation demanded for violations. ${ }^{23}$ That this important legal development occurred at the same time in the early eighteenth century as the drawing of law-codes (kānūnnāme), especially that of the admiral Mezamorta Hüseyin Pasha in 1701 to reform Ottoman naval organization, shows this was part of a wider trend of innovative

20 On the Adriatic, see: Egidio Ivetic, "The Peace of Passarowitz in Venice's Balkan Policy" in The Peace of Passarowitz, 1718, ed. Charles Ingrao and Nicola Samardžić (West Lafayette IN, 2011). On later developments after the collapse of Venetian power: Kahraman Şakul, “Osmanlılar Fransız İhtilali'ne Karşı: Adriyatik ve İtalya Sularında Osmanlı Donanması" in Nizam-ı Kadim'den Nizam-ı Cedid'e: III. Selim ve Dönemi (Istanbul, 2010), 255-315.

Rifaat A. Abou-El-Haj, "The Formal Closure of the Ottoman Frontier in Europe, 1699-1703," Journal of the American Oriental Society 89 (1969): 467-475. Carlowitz is about to undergo a long-overdue reassessment: Colin Heywood and Ivan Parvev, eds., From War to Peace: The Ottoman 'Long War' with the Lega Sacra Powers, $1683-1699$ (Leiden, forthcoming).

See: Colin Heywood, "The Kapudan Pasha, the English Ambassador, and the Blackham Frigate: An Episode in Anglo-Ottoman maritime relations (1697)," in The Kapudan Pasha, His Office and His Domain: Proceedings of the 4th Halcyon Days Conference, ed. E. Zachariadou (Rethymno, 2002), 409-438.

Talbot, “Ottoman Seas," 59-64. 
maritime thought. ${ }^{24}$ Crucially, the extension of Ottoman authority out into the open sea did not represent a permanent claim to authority, but a temporary measure to ensure security in Ottoman territorial waters, defined as being up to three miles from the shoreline.

In some respects, these new naval tactics might be representative of an empire under siege, to borrow Virginia Aksan's term, who argues in her important study that, following the conquest of Crete in 1669, the Ottoman state relied more on land-based defensive systems than on its fleet, a view backed up by Molly Greene's research on Crete in the later seventeenth century. ${ }^{25}$ Certainly, a great deal of effort and expense went into constructing or repairing coastal fortifications, and, prior to 1718 , the term muhăfaza was most commonly used to refer to the strengthening of fortifications or the defense of a castle during a siege, or, if water was involved, to protecting strategic rivers like the Danube. ${ }^{26}$ The maritime regulations, in establishing a buffer zone, were themselves a legal kind of fortification. The growing investment in naval patrols as a major duty of the Ottoman fleet in this period therefore denotes a developing sense of territorial space in the Mediterranean, one that required the same protective care as the fortresses that marked Ottoman military and political authority across the empire, but also carries with it a definite connotation of defensive protection. That is, at the same time as these fixed land borders and set maritime spaces were being recognized, the Ottoman state became more assertive in protecting its waters from violence, increasingly at the instigation of littoral subjects.

In previous decades, the primary function of the Ottoman navy in the Aegean and Eastern Mediterranean had been in engaging foreign navies during the wars, chasing and fighting the various Christian corsairs who raided

24 Yusuf Alperen Aydın, "Reform of the Ottoman navy and Ottoman superiority at sea (17011718)" in Guido and Lo Basso, Mutazioni e permanenze, 163-179; İdris Bostan, "Kadırga'dan kalyon'a: XVıI. yüzyılın ikinci yarısında Osmanlı gemi teknolojisinin değişimi," Journal of Ottoman Studies 24 (2004): 65-86; İdris Bostan, "Mezamorta Hüseyin Paşa ve 1701 Tarihli Bahriye Kanunnamesi” in İdris Bostan and Salih Özbaran, eds., Başlangıçtan XVII. Yüzyılın Sonuna Kadar Türk Denizcilik Tarihi 1 (Istanbul, 2009), 281-291, esp. 284-288.

25 Virginia Aksan, Ottoman Wars, 1700-1870: An Empire under Siege (Abingdon/New York, 2007), 9; Molly Greene, "Ruling an Island Without a Navy: A Comparative View of Venetian and Ottoman Crete," Oriente Moderno 20 (2001): 193-207, esp. 205-7.

26 воА/С.вн.181/8494 (25 Şaban 1110 / 26 February 1699). See: Rossita Gradeva, "War and Peace along the Danube: Vidin at the end of the seventeenth century," Oriente Moderno $20(81)$, no. 1 (2001), 149-175. 
Ottoman waters, and collecting taxes from the island communities. ${ }^{27}$ The growing investment in protection after 1718 seems to reflect new ideas of spatial authority on the part of the state requiring a new level of engagement with its subjects, and as a means of consolidation after the recapture of Morea in 1715 -itself frequently referred to as an island (cezire) - and the naval conflict against Venice in the Aegean, both of which resulted in the formal settling of both maritime and land borders in the Adriatic. ${ }^{28}$ This is not to say that prior to ideas of fixed sovereignty confirmed in 1718 the Ottoman state had been laissez-faire with regard to maritime security, with operations described as muhäfaza carried out by the Ottoman navy in Crete in 1695, Salonica in 1702, the Aegean islands in 1706, and Alexandria in $1709 .{ }^{29}$ Indeed, an examination of earlier Ottoman records from the sixteenth and seventeenth century show the importance of muhäfaza through naval missions and patrols as an established practice, from the command issued to the provincial governors of Aydın and Saruhan to give logistical support to a certain Mehmed Bey engaged in protecting the sea (deryā muhăfaza) in the Aegean in 156o, to more detailed commands later on, such as that to the admiral Ali Paşa in 1617 allotting a significant number of ships "necessary to protect and guard the Well-Protected Domains, and for the security and welfare of the ships of merchants and visitors" from pirate attacks around the coasts of Morea. ${ }^{30}$ By 1718, muhăfaza was already a longstanding part of Ottoman maritime vocabulary.

The eighteenth century is different for three reasons in assessing muhăfaza at sea. First, we have a greater amount of surviving documentation that gives a deeper insight into maritime practices than is possible with the material from earlier centuries. Second, this period saw European wars brought to Ottoman

27 E.g., BOA, Ali Emiri Tasnifi, III Ahmet (Ali Emiri Series, Ahmed III, AE.SAm D.III.) 87/8655 (end of Zilhicce 1115/ beginning of May 1704).

28 Ivetic, "Peace of Passarowitz," 66-68. On Morea as an island, see: Kahraman Şakul, "The Ottoman Peloponnese before the Greek Revolution: 'A republic of ayan, hakim, and koçabaşı' in 'the sea of humans and valley of castles,"' in a forthcoming edition of Princeton Papers on Ottoman insularity edited by Antonis Hadjikyriacou.

во, İbnülemin Tasnifi, Bahriye (İbülemin Series, Naval, İE.BH.) 11/1026 (1 Şevval 1106/ 15 May 1695); їЕ.вH.11/981, 11/986, 11/998 (10 Receb 1113/ 11 December 1701); İ.BH.12/1113, 12/1115, 12/1116 (beginning of Ramazan 1118/ beginning of December 1706); C.BH.15/722 (12 Şevval 1121 / 14 December 1709). On the seventeenth-century navy in general, see İdris Bostan, Osmanlı Bahriye Teşkilatı:XVII. Yuzyılda Tersâne-i Âmire (Ankara, 1998).

30 воА, Mühimme Defterleri (Registers of Orders, MD), III. nos.18, 761; вOA, MD.LXXXII, no.233. The Mühimme Registers are full of examples of commands relating to naval protection missions in this earlier period, and my thanks go to Emrah Safa Gürkan for his advice on locating examples in these sources. 
waters through large numbers of privateers, creating new dangers for Ottoman shipping due to an ever-increasing quantity of Ottoman goods freighted on European ships. Third, the fixing of borders in 1699 and 1718 meant that maritime territoriality was a definable and implementable concept, particularly given that treaties like Passarowitz made explicit mention of the sea as a legal space.

In the fifteenth article of the Venetian text of that treaty, it specifically set forth that "the subjects of both powers may trade on land and at sea in perpetual peace, security, and free from all impediment."31 The importance of the phrase "on land and at sea"-tam terra quam mari-for the freedom of commerce in particular is a nod to the basic freedoms granted in almost all of the Capitulations granted by the Ottoman Empire. However, that sea, an undefined derya or mare, was different from a territorial sea. Nor were territorial waters explained in the treaty, so that border lines went "straight towards the sea" (recta versus mare), but not into it. ${ }^{32}$ The fact that the "Archipelago"- the Ionian Islands—-was mentioned as being part of the fixed borders (parte finibus) may indicate some sense of the sea as a boundary. ${ }^{33}$ However, in the treaty with the Habsburgs at Passarowitz, a clear sense of maritime territoriality is given in the thirteenth article, which relates to the coastal stronghold of Ülgün (also known at the time as Dulcigno, today's Ulcinj in Albania), notorious as a center of piracy in the Adriatic into the eighteenth century. ${ }^{34}$

Ottoman Turkish text:

[...] Likewise, the inhabitants of the citadel of Ülgün situated on the seacoast, having been going out corsairing, their frigates and other pirate ships shall be confiscated in order that they shall not harm merchant ships, they shall be prohibited completely from attacking merchant ships, and henceforth it is decreed that they may not construct [ships]. Consequently, any of them who act or behave contrary to the imperial command and against the [established] peace and harmony by daring to bring havoc upon merchant ships through their plundering and looting shall restore any of the goods and wares that they hold and possess,

31 Treaties between Turkey and Foreign Powers (London, 1855), 743.

32 Ibid., 739 .

33 Ibid., 739-740.

34 The so-called "Dulcigno Pirates" are still relatively understudied, particularly for the eighteenth century. On piracy in the Adriatic after the Ottoman conquest of Albania, see: İdris Bostan, Adriyatik'te Korsanlı: Osmanlılar, Uskoklar, Venedikler, 1575-1620 (Istanbul, 2009). 
and if they have caused any damage or losses they themselves are to compensate for them [şöyle ki içlerinden fermān-ı hümāyūna muhălif ve

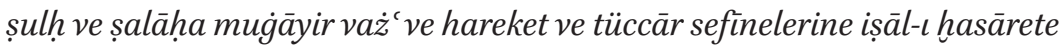
cesāret eydenleriñ nehb ve ġäret eyledikleri emvāl ve eşyā her ne ise gïr ve șăhiblerine istirdād ve vāka $a^{\prime}$ olan żarar ve ziyān kendülerden tażmin]. Moreover, if they enslave any person, they are to free them from slavery. In addition, if a punishment is to be drawn up for their crime arising from the requirements of the [Islamic] law in order to make an example of this sort of banditry to others, it shall arise from firm justice. In order to secure and protect commercial traffic from disturbance and conflict, the two sides are to fix and appoint agents for the ease of engaging in any sort of dialogue, and if a judgment is given, it is to be included in and appended to the treaty so that it will be observed by and enforced upon all. ${ }^{35}$

Latin text:

[...] Likewise, the inhabitants of the stronghold of Ülgün situated on the seacoast are to be restrained from engaging in piracy henceforth, and shall be forbidden from harassing or harming merchant ships, as well as from building themselves piratical barques, frigates, and other ships to replace those taken from them. Consequently, such plunderers that should presume to harm merchant ships contrary to the imperial capitulations shall restore all the goods and wares that they have plundered, provide compensation for damages and losses [ita quidem, ut in tales prcedones, qui contra imperiales pacis capitulationes mercatorum navibus damna invehere, easque aggredi ausi fuerint, restitutis omnibus in prcedam ablatis rebus et bonis, resarcitisque damnis et iacturis], and free prisoners that they have taken, and, justice being sought in order to made an example to others, they are to be punished according to the laws. In order that all commerce be free from ill-intent, whatever those appointed by the [treaty] commissioners from both sides to handle [any dispute] shall conclude and determine will be confirmed, and inserted in and appended to the capitulations. ${ }^{36}$

воА, Düvel-i Ecnebiye Defterleri, Nemçelü Ahidname Defteri (Registers of Foreign States, Austrian Treaties, A.DVNS.DVE.d.57/1), fol. 59 .

$36 \quad$ Treaties between Turkey and Foreign Powers, 74. 
Moreover, there are important similarities between the legal thinking behind these clauses of the treaties drawn up in 1718 and the maritime regulations governing European privateers first instituted in 1696 by the Ottoman admiral Mezamora Hüseyin, noted in this account by the British consul in Izmir, William Raye:

[...] After reciting former difference betwixt the English, French, and Dutch nations, he declares that from Andro[s] and Stanchoi [Kos] hither [i.e. to Foça near Izmir] no acts of hostility should be committed; and that if any ship acted contrary thereto and took any other within those limits, he did engage to the party suffering that restitution should be entirely made him for all damages sustained by the captor. ${ }^{37}$

The common features here are that there were set spaces within which maritime violence was prohibited - the entire Adriatic for the Ülgün pirates and most of the Aegean for the European privateers - and that those who committed any depredations were themselves obliged to restore the goods they had taken and/or to pay full compensation for any losses. This goes far beyond notions of maritime authority expressed in earlier treaties.

From the Ottoman response to British and French privateers in the 1690 s and 1700s, it seems clear that borders and territoriality were becoming part of Ottoman maritime discourse, and this immediately changes what it meant to patrol in a certain liquid space. In addition to the three key developments of more sources, new forms of threat, and a sense of legal maritime spaces, were two further interlinked factors that shaped the development of maritime muhăfaza in the eighteenth century: the increased risk of disruption to mercantile shipping, particularly given the growing role of European freighters in Ottoman trade and the growing level of international trade around the Ottoman realms in general; and numerous famines at various times across the eastern Mediterranean, a major factor, for instance, in the dispatch of ships to protect merchants sailing on a key shipping route between Syria and Egypt from pirate attacks in the open waters beyond the Egyptian and Palestinian coasts in $1710 .{ }^{38}$

The period after Passarowitz therefore represents a convergence of all of these factors, and this helps to explain why we begin to see concerted efforts to invest in and consolidate a regular naval presence in the Mediterranean

School of Oriental and African Studies (sOAS), Special Collections, Paget Papers (SC.PP) 5/27(iii), William Raye to Lord Paget, 3 July 1696.

38 вОА/С.BH.91/4391 (10 Rebiülevvel 1122 / 9 May 1710). 
from this point, with extraordinary legal measures applied in times of heightened threat. In September 1719, a naval commander, a certain Mehmed Kapudan, was "appointed for the duty of protection to the Mediterranean Sea" (Ak Deñiz cānibine hizmet-i muhāfazaya me'mūr olan), tasked with taking the fleet based in Bodrum from the island of Kos to Kalymnos, Leros, Patmos, Icaria, across the "gulf of Samos," and to the island of Chios, a journey of some 200 kilometers. $^{39}$ This was not the only muhäfaza operation launched in that year, with one Hasan Kapudan appointed for that purpose to the island of Euboea (Ağrıboz), and both these missions represent a centrally-directed defensive deterrent against maritime violence across a broad space of Ottoman waters. ${ }^{40}$ The area of Mehmed Kapudan's patrol is notable in being the space within which the maritime regulations against European privateers had been enforced through the 1696 and 1703 regulations, where the Venetian fleet had sailed prior to the Battle of Imbros in 1717, and through which a significant amount of international and domestic freight passed to and from Izmir and Istanbul. Between the missions of the naval commanders Mehmed in the eastern Aegean and Hasan in the west, the Ottoman fleet was marking out a part of the Mediterranean that could be claimed as Ottoman. This delineation of the Mediterranean as an abstract unitary space-Aḳ Deñiz cānibine, literally to the area, direction, or side of the Mediterranean-punctuated by stops in islands or ports, supports Marinos Sariyannis's assertion in his wonderful article on a seventeenth-century Ottoman pirate novel, that "one could even say there is no Mediterranean Sea in the narrative; there are only itineraries." ${ }^{41}$ However, in many of the documents regarding naval protection in the eighteenth century, the sole description of their patrol territory was the Mediterranean cannib. Itineraries were for the benefit of the captains; the Ottoman state tended to think about and therefore describe a more general Mediterranean territorial space.

Whilst protecting against pirates and corsairs, the Ottoman fleet did not itself discard corsairing as a more proactive tactic against maritime violence. ${ }^{42}$ In 1722, a report reached Istanbul from the province of Sayda detailing unrest off the Palestinian and Syrian coasts, particularly around the port of Haifa, which had become a refuge for "infidel pirates to take on water and find safety

39 воA/ї.вн.16/1442 (14 Zilkade 1131 / 28 September 1719).

40 BОA/i E.BH.18/1627 (16 Şevval 1131 / 1 September 1719).

41 Marinos Sariyannis, "Images of the Mediterranean in an Ottoman Pirate Novel from the Late Seventeenth Century," Osmanlı Araştırmaları / The Journal of Ottoman Studies 39 (2012): 189-204 at 201.

42 Brummett, Ottoman Seapower, 96-99. 
from danger."43 Describing the Haifa pirates as infidel (kefere) is an example of the most common adjective to describe the perpetrators of maritime violence, and could simply be a means of emphasizing their criminality, but taking the adjective to simply mean non-Muslim, it could be referring to any of the Christian corsairs. ${ }^{44}$ In this case, however, given that Maltese pirates frequently raided Haifa in this period, it is not inconceivable that they could be the culprits here. ${ }^{45}$ It was resolved to strengthen the port's fortifications, increase the garrison, and dispatch imperial ships so that "the shores of Arabia do not remain in the hands of infidel pirates."46 Although the mission to Haifa was described in this particular command as one of muhäfaza, another from the same year describes the galleon Küşs Bäğçeli (The Bird Garden) as being "sent to the Mediterranean in order to engage in corsairing (korșanlık)." ${ }^{47} \mathrm{Ku}$ ş $B \bar{a} \dot{g} c$ eli was to take a number of soldiers to the port of Tripoli (in Syria), and then "be appointed to cruise in the ports of Tripoli and Sidon and in their environs, in order to guard and protect them from infidel pirates." ${ }^{38}$ Thus, a galleon of the Ottoman imperial fleet was sent on a corsairing mission to protect Ottoman waters and ports in the Levant from pirates and corsairs; it could be said that corsairing was the active form of defensive muhăfaza. ${ }^{49}$

43 воA/С.вн.158/7510 (2 Zilhicce 1134 / 13 September 1722). See: Thomas Philipp, Acre: The Rise and Fall of a Palestinian City (New York, 2001), 97; Mahmoud Yazbak, Haifa in the Late Ottoman Period, 1864-1914: A Muslim Town in Transition (Leiden, 1998), 9-13; Amnon Cohen, “Te'udot 'Othmaniot 'al benyinah shel Ḥeyfah be-me’ah ha-18," 'Erets-Yiśra'el: Meḥkarim be-Yediy'at ha-'Erets ye 'Atikotiyah (1971), 152-159.

44 For a recent reassessment of Christian pirates and corsairs in the Mediterranean, see: Molly Greene, Catholic Pirates and Greek Merchants: A Maritime History of the Early Modern Mediterranean (Princeton, 2010), especially 78-137.

45 On the Maltese corsairs in general, see: Michel Fontenay, «Corsaires de la foi ou rentiers du sol? Les Chevaliers de Malte dans le corso méditerranée au XVII ${ }^{\mathrm{e}}$ siècle, » Revue d'histoire moderne et contemporaine 35 (1988): 361-384. For the eighteenth century: Michel Fontenay, "Les derniers feux du 'corso' chrétien à Malte (1678-1798)" in Méditerranée, mer ouverte: Actes du colloque de Marseille, 21-23 septembre 1995, ed. Christane VillainGandossi, Louis Durteste and Salvino Busuttil (Aix-en-Provence, 1997), vol. 1: 209-226; Robert Cavaliero, "The decline of the Maltese corso in the eighteenth century: A study in maritime history," Melita Historica 2 (1959): 224-238. ВОА/С.вн.158/7510.

47 воА/С.вн.122/5928 (26 Cemaziülevvel 1134 / 14 March 1722). In terms of currency, there

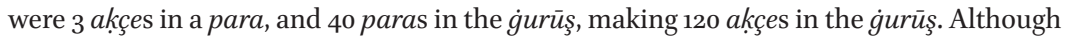
many calculations were still made in akçes, the main unit of account was the $\dot{g} u r u \bar{s}$.

48 Ibid.

49 For a similar case, see: вОА/С.BH.228/10553 (1143/ second half of 1731). 
As the example of Haifa shows, as well as being detrimental to seaborne trade, maritime violence greatly affected Ottoman coastal settlements, often leading those communities to seek assistance from the state. In 1729, a petition was dispatched by Mehmed Emin, a senior qadi on Samos, writing that "all of the subjects of the island of Samos had come to the shari'a court to make a declaration. ${ }^{50}$ He complained that the chief monk serving as the island's despot (despottdar) had colluded with "evil men and bandits together with pirate ships," and that "he has given [the bandits and pirates] grain from our island [and] recently he has taken figs and grapes from a number of Muslim ships, laden them on a caïque, and sent it to Istanbul. ${ }^{51}$ Violence such as this provided a challenge to imperial authority in the provinces, especially when local notables became involved. At the same time, such incidents provided the state with the opportunity to enforce its presence on its coasts and islands, often, as in this case, at the request of their own subjects.

The increasing call from the provinces for protection and the general peace on the western frontiers after 1718 meant that by the later 1730 s the Ottoman fleet was expanding the scale of its patrols in the Mediterranean. The war with Russia and the Habsburgs between 1735 and 1739 seems to have increased protection missions in the face of potential foreign threats, so that a fleet of seven ships was prepared for duty in the Mediterranean in $1736 .{ }^{52}$ Such a high level of deployment came with significant expenditure. Documents for the year 1150 (1737/8) give an insight into the amount of paperwork and expense involved in organizing the fleet, of which the following are indicative examples. In November 1737, approval was given for the provisioning of the caravels $\dot{G} a z \bar{a} l e$ (The Hind) and Şehbāz-ı Bahrī (The Royal Falcon of the Sea) and their combined crew of 650 levends (independent mercenary soldiers) and 30 slaves, comprising 300 kiles of rice, 650 kiles of lentils, 2,990 okkas of olive oil, 6o kiles of wheat, and 1,422 kantars of hardtack. ${ }^{53}$ This required the services of a number of different departments of state, so that the rice, lentils, and wheat were to be procured by the chief of the imperial kitchens (mațbah-ı 'ämire emini), and the olive oil by the head customs official (gümrūk emini). Similarly, in the

50 вОA, Cevdet Tasnifi, Zabtiye (Cevdet Series, Security, С.zв.) 5/201 (15 Rebiülahir 1142 / 7 November 1729).

$51 \quad$ Ibid.

52 вОА/С.вн.121/5883 (first half of 1149 / first half of 1736 ).

53 вОА/С.вH.120/5827 (29 Receb 1150 / 22 September 1737). In Istanbul terms, the kanțar weighed around $56.44 \mathrm{~kg}$, whilst the kile was equivalent to about $25.66 \mathrm{~kg}$, the subunit of which was the okka of around $1.28 \mathrm{~kg}$. On the use of levends, see: Aksan, Ottoman Wars, $56-57$. 
autumn of 1738 , seven ships with crews totalling 1,830 levends and 68 slaves were supplied with 3,66o kiles of brown rice, 1,830 kiles of lentils, 136 kiles of wheat, 8,694 okkas of olive oil, and 4,012 kantars of hardtack, with the provisions coming from the imperial storehouse (kilār-ı 'āmire) and dockyards (tersāne-ı 'ämire), the customs office, and a number of private merchants. And it was not just the center bearing the burden. A document concerning the dispatch of two ships in 1732 to protect the coast around Antalya from pirates explained that 240,000 akçes $(2,000$ gurūşs) would be required from revenue of the Antalya customs tax-farm for the costs of the mission. ${ }^{54}$ In other words, the costs of maintaining, equipping, and manning the ships on muhăfaza missions was to be paid, in certain cases, not from the coffers of central government in Istanbul, but from the revenue of tax-farms in the areas to be protected (known as the ocakllk system).

From these documents, representative of a significant number of records detailing expenditure on the Ottoman navy in this period, we can get a sense of the manpower, provisions, cost, and organizational effort required to send these ships to the Mediterranean. The fact that a number of ships with crews of between three and four hundred levends were active in those waters on rotation demonstrates the Ottoman government's commitment to naval protection in terms of deployment and expenditure. By the later 1730s, the Ottoman fleet was developing protective corsairing forays into regular preventative or deterrent muhăfaza missions, shifting from mobilization due to the conflict with Russia and the Habsburgs into a concerted effort to simultaneously assert a defensive presence in Ottoman waters and provide Ottoman subjects with protection from korsans of all descriptions, often at the request of provincial subjects who, through ocaklık, also began to take on some of the financial burden. However, it would be the tumult of the 1740 s and 175 os that would really solidify the role of muhăfaza missions in response to ongoing corsair attacks and a growing threat of European privateers.

\section{Mụ̣äfaza in Peace, Famine, and International Conflict, 1740-1763}

Although the Ottoman Empire was at peace with its European neighbors in the years between the Treaty of Belgrade in 1739 and the outbreak of war with Russia in 1768 , the eastern Mediterranean saw a sustained period of violence against Ottoman shipping and subjects, in part at the hands of Maltese corsairs and Morean pirates, but also due to inter-European conflicts bringing 
privateering wars into Ottoman waters. Anti-piracy measures consequently took on new legal, spatial, and diplomatic dimensions. A beginning of this process can be traced to an imperial command issued in March 1740. A complaint had been made by the Venetian ambassador that a Venetian ship going into the open sea (rūy-u deryāya) carrying goods of Ottoman Muslims and non-Muslims living in the Mediterranean had been set upon by a pirate ship. ${ }^{55}$ Action was requested to protect trade routes to the Ottoman Empire and to Venice, and specifically to defend "persons and their goods from being set upon by infidel pirates causing damage and harm." 56 This, of course, harks back to the agreements reached at Passarowitz. Consequently, measures were taken to alert the judges, governors, commanders, and castellans in Salonica, Euobea, Morea, Sidon, Tripoli, Rhodes, Antalya, and Cyprus, and to increase coastal garrisons where necessary.

As with the case of Haifa twenty years earlier, moves to strengthen coastal fortifications were soon followed by naval action, so that in October 1740, eight galleons were ordered to be sent to the Mediterranean. ${ }^{57}$ This was followed in January 1741 by a command issued to a number of senior naval officers under the commander responsible for Mediterranean protection, Küçük Ahmed Kapudan, reporting that "a polacca and a saitee from among the corsair ships of the Maltese infidels concealed themselves in Porto Koufo, near to the island of Kassandra (one of the dependents of Salonica), and in the dead of night raided the said island," resulting in a local notable being enslaved along with his two servants, their goods looted and pillaged. ${ }^{58}$ As a result, Ottoman warships were to "prepare for the duty of protecting and securing the Mediterranean from piratical banditry," and to "secure the waters of my Well-Protected Domains from the ravages of the pirates." ${ }^{.59}$ Moreover, with an increasing number of European states holding Capitulations guaranteeing free movement and right to trade, the international dimensions of maritime security were addressed by ensuring that "those who come and go to the waters of my Well-Protected Domains with their flag and passports shall in every way be shielded from attack." ${ }^{\prime 0}$ With an eye to domestic as well as international

\footnotetext{
55 BOA, Ali Emiri Tasnifi, I. Mahmud (Ali Emiri Series, Mahmud I, AE.SM HD.I.) 25/1477 (end of Zilhicce 1152 / end of March 1740).

56 Ibid.

57 ВОА/С.вн.233/10805 (12 Receb 1153 / 3 October 1740).

58 BOA/AE.SM HD.I.58/3697 (middle of Şevval 1153 / 3 January 1741). See also: C.BH.225/10471 (middle of Zilhicce 1153 / beginning of March 1741).

59 BOA/AE.SMHD.I.58/3697.

6o Ibid.
} 
commerce, the fleet was reminded of the importance of "protecting and securing the grain-purchasing ships coming to Salonica and its environs." ${ }^{\prime 1}$ Guarding the Mediterranean therefore entailed protecting both Ottoman territory and Ottoman and müste'min trade.

The three imperial commands of 1740 and 1741 were issued in a pivotal period marked by three main themes. First, the Treaty of Belgrade in 1739 had secured a reasonable peace on the Ottomans' western borders, effectively ending the Ottoman-Habsburg conflicts (the brief conflict of 1787-91 excepted), and giving a pause in the wars with Russia for almost thirty years, allowing the Ottoman fleet to focus on maintaining local order. Second, the Ottoman provinces were experiencing hardships due to extreme climatic events, notably the famine in the Levant during $1740-5 .{ }^{62}$ The later eighteenth century saw Anatolia and Syria hit by serious food shortages, making the protection of maritime supply lines absolutely vital. Third, in the 1740s-176os the impact of European political struggles would make itself dramatically felt in the Ottoman Mediterranean. The 1740 s saw the arrival of intense European privateering in the eastern Mediterranean as the War of the Austrian Succession (1740-8), and, after a brief respite, the Seven Years' War (1756-63) saw the violence return, with the major European powers such as France, Britain, Spain, Holland, and others, involved in both conflicts that spilled into the Eastern Mediterranean in different alliance combinations. Privateering and continued corsair attacks threatened Ottoman supply routes and territorial integrity at a time of high demand for food staples, and when stable peace agreements saw the Ottoman state keen and able to assert its territorial sovereignty at sea.

A number of imperial commands and financial documents record the mobilization of the fleet for regular anti-piracy patrols from the beginning of the 1740 s. In the summer of 1740 , the vice-admiral's flagship was tasked with "protecting the ships freighting wheat from the port of Volos to the Abode of Felicity [Istanbul] from the seizures and attacks of infidel pirates in the Mediterranean Sea." ${ }^{63}$ The unusually high number of fourteen frigates were sent for muhăfaza in 1740-1 and ten in 1741-2. ${ }^{64}$ Coordination was also made with land defenses, with the appointment of Seyid Mehmed Kapudan in 1742 to cruise along the coast of Crete to complement the strengthening of

\footnotetext{
$61 \quad$ Ibid.

62 Yaron Ayalon, Natural Disasters in the Ottoman Empire: Plague, Famine, and Other Misfortunes (Cambridge, 2015), 18. See also: Sam White, "The Real Little Ice Age," Journal of Interdisciplinary History 44 (2014): 327-352.

63 вОА/С.вH.168/7928 (23 Rebiülahir 1153 / 17 July 1740).

64 воА/С.вн.86/4131 (28 Şevval 1155 / 26 December 1742).
} 
the garrisons of the castles of Rethymno and Chania, part of a broad effort "to protect the poor people of the realm from the oppressive acts of piratical banditry." 65 Moreover, corsairing remained an option, with a number of galleons recorded as being engaged in that activity around the Aegean Islands in $1741 .{ }^{66}$

The arrival of British and French privateers in Ottoman waters in the late 1740 s proved to be a significant moment that defined the relationship between the Ottoman state and the Mediterranean Sea in times of emergency. This was largely driven by the complaints and pleas for assistance from Ottoman officials and merchants from around the Mediterranean. For instance, a petition was submitted to the central government by the qadi of Tuzla on Cyprus near the war's end in May 1748, reporting that the British consul, George Wakeman, had gone to the shari'a court to give a formal representation (takrīr). ${ }^{67}$ Wakeman complained that a French privateer had taken a Dutch ship under the cannons of the port, an action described by Wakeman (via the qadi) as "contrary to the imperial capitulations and contrary to the exalted command."68 This petition formed part of the legal battle that accompanied the violence at sea, with the "exalted command" referring to the new maritime regulations.

The basis of the legal defense against privateers from friendly nations such as the British and French was a dramatic extension of the maritime regulations first instituted against European privateers in 1696 and again in 1703, which forbade armed European ships from committing acts of violence anywhere in the Aegean Sea, even beyond the coastal waters. Unlike other initiatives used to govern Ottoman maritime space, such as the permissions for sailing in certain waters such as the Dardanelles (the $i z n-i$ sefine), the commercial agreements that later regulated contentious spaces such as the Black Sea, or indeed the prohibition on Adriatic piracy set down at Passarowitz, were temporary and extraordinary measures used at key moments in the eighteenth century to halt European privateering violence.$^{69}$ In the 1740 s, in response to a number

65 вОА/С.BH.213/9933 (19 Cemaziülahir 1155 / 20 August 1742).

66 вОА/С.вн.87/416o (15 Şevval 1154 / 24 December 1741).

67 BOA/AE.SM HD.I.34/1981 (18 Cemaziülevvel 1161 / 13 May 1748). On takrïrs: Michael Talbot, "Petitions of the Supplicant Ambassador: British Commercial Representations to the Ottoman State in the Eighteenth Century," Journal of Ottoman Studies 46 (2015): 163-191.

68 BOA/AE.SMHD.I.34/1981.

69 On the naval permissions, see: Hamiyet Sezer, "Osmanlı İmparatorluğu'nda Seyahat İzinleri, 18-19 yüzyll," Ankara Üniversitesi Dilve Tarih-Coğrafya Fakültesi Tarih Bölümü Tarih Araştırmaları Dergisi 21 (2003), 105-124; Talbot, "Petitions of the Supplicant Ambassador," 171-177. On later developments in the Black Sea, particularly relating to trade see: İdris Bostan, “İzn-i Sefine Defterleri ve Karadeniz’de Rusya ile Ticaret Yapan Devleti-i Aliyye 
of attacks against ships carrying Ottoman goods and subjects, and fighting occurring a short distance off the Ottoman coast under the guns of coastal fortifications and within harbors, the Ottoman government reinstituted and extended these regulations. Two crucial commands were issued in March and October 1744. The first reported two British privateers cruising in the waters around the islands of Kefalonia and Lefkada (Aya Mavro) making attacks on French ships around Ottoman ports. ${ }^{70}$ In response, the Ottoman government informed the Mediterranean governors and commanders that such actions were contrary to the Capitulations and that attacks were not permitted within a number of miles (bir kaç mīl) of the Ottoman coast. As the violence continued, the more forceful October command was issued to Ottoman officials and European diplomats, fixing a border (hadd) across the sea beyond which attacks by armed European ships would no longer be tolerated, to wit between Morea and the Gulf of Sirte in Libya. ${ }^{71}$ This command, an important innovation in Ottoman maritime legal practice, specifically employed the language of protection, emphasizing that the new measures were "to protect and guard the subjects and merchants of my Sublime State from harm" (Devlet-i 'Aliyem re'āya ve tüccārını żarar ve hasāretden muhăfaza ve șiyānet). ${ }^{72}$ This idea of protection was of course not novel in sentiment, taking the earlier regulations even further, but the legal and political implications of shutting off a huge amount of maritime space beyond ordinary territorial waters is indicative of both the need to establish a significant buffer zone and an attempt to find a non-violent and effective solution to the growing violence of supposedly friendly states.

The British chargé d'affaires, Stanhope Aspinwall, wrote to London full of sympathy for the Ottoman position, but skeptical as to the practicalities of enforcing such a legal space:

[O] ur privateers in the midst of a sea of sixty-six leagues large could not possibly tell whether they were got into the seas of the Porte or no, and in

Tüccarları, 1780-1846" in İdris Bostan, ed., Beylikten İmparatorluğa Osmanlı Denizciliği (Istanbul, 2006), 353-394, especially 366-373 on the later eighteenth century; Kemal Beydilli, "Karadeniz Kapalılığı Karşısında Avrupa Küçük Devletleri ve 'Miri Ticareti' Teşebbüsü," Belleten 55 (1991), 687-755, particularly the discussions on 689-695.

70 воA, Cevdet Tasnifi, Hariciye (Cevdet Series, Foreign, C.Hr.) 140/6968 (end of Muharrem 1157 / mid-March 1744).

71 BOA/C.HR.121/6030 (end of Şaban 1157 / beginning of October 1744).

72 Although it is usual for Ottoman commands to contain near-synonymic word-pairs (e.g. muhăfaza ve hırāset) the choice here of muhāfaza and șiyānet is interesting, with the former holding defensive connotations and the latter having the sense of being more proactive. 
bad weather may roam the seas several days without knowing it, as they cannot see even the coasts of either side; and there, in case of a capture, how could either the captor know it to be taken, or the prize make it appear he was taken, out of bounds? So that a line to be drawn across so large a sea is the most chimerical thing that was ever imagined. ${ }^{73}$

Despite reasonable objections to the new regulations, Aspinwall had not considered the cooperation of provincial authorities and merchants. In September 1745, in direct contravention of the new regulations, the British ship HMS Diamond chased a French vessel near the port of Foça, near Izmir. On seeing this, the governor of the castle fired three warning shots from the castle's cannon and detained a number of British merchants to ensure the ship's good behavior. Aspinwall considered this a gross insult and protested to the Ottoman government. ${ }^{74}$ However, after an investigation by the commander of an Ottoman Aegean fleet that visited Foça, it was confirmed that the Diamond had indeed been pursuing a passing a French ship in these restricted waters. ${ }^{75}$ Moreover, this violation was recorded at the time and in situ by a declaration lodged with the qadi of Foça, signed by fifty-six Muslim notables and merchants of the town. ${ }^{76}$ This provided incontrovertible proof for the Ottoman government that the British had violated the maritime regulations.

Things reached a head with the rampage of a British privateer named Fortunatus Wright, captain of The Fame. Among the archival records of the British embassy in Istanbul are documents of aggrieved Ottoman merchants, including the losses of one group attacked on board a French ship that they were freighting to Crete. First, they lodged inventories of their goods with the customs official via the qadi court in Candia, which were subsequently translated and registered in the embassy's chancery. ${ }^{77}$ Then, the merchants arrived in person at the British embassy to register their claim against the privateer, amounting to the huge sum of 20,420 giuruss.. ${ }^{78}$ The combined pressure of the

73 The National Archives, UK (TNA), State Papers (SP) 97/32 Stanhope Aspinwall to the Duke of Newcastle (12 May 1744). TNA/sP 97/32 Aspinwall to Newcastle (24 September 1745).

75 TNA/sP 97/32 Aspinwall to Newcastle (9 November 1745).

76 вOA, Düvel-i Ecnebiye 3 (Foreign States, 3 (Britain) A.DVN.DVE.3) 81/6 (19 Ramazan 1158 / 15 October 1745).

77 TNA/sp 97/32 "Carto d'oglio, sappone, e d'altre mercanzie sopra la nave francese di Capitan Blanc nella scala di Candia destinado per Alessandria” (19 Cemaziülevvel 1159 / 5 June 1746); "Note delle robbe appartenente alli mercanti e passaggieri turchi imbarcatisi nella nave di Capitan Blanc, francese [...]" (15 Cemaziülevvel 1159 / 5 June 1746). TNA/sP 97/32 Sealed registration of the merchants' claims (19 August 1746). 
Ottoman merchants, and the insistence of the Ottoman state upon the British authorities led the Levant Company, the commercial monopoly that financed the British embassy and oversaw British trade in the Ottoman Empire, fearing that its merchants' trade would suffer, to pay compensation in this case as in many others, totalling over 100,000 gurüş for depredations made off the coasts of Crete, Cyprus, and Syria between 1744 and $1747 .^{79}$

The legal aspect of the Ottoman anti-privateering strategy in the 1740s was a significant development in the Ottoman approach to müste'min violence off its coasts. However, naval patrols continued in earnest around the Mediterranean, with a number of ships recorded as undertaking such missions throughout the conflict, rising from around five in 1743 to no less than thirteen engaged on muhäfaza duty in the Mediterranean in 1748, the great expense of keeping them operational mitigated through provincial contributions. ${ }^{80}$ Yet, despite the new maritime regulations, and the increasing presence of Ottoman ships on protection duty, little seemed to work to actually stop the attacks of the British privateers.

In the brief period of peace that followed after 1748, the threat from Maltese and other corsairs and pirates remained, and so defensive patrolling continued. ${ }^{81}$ Moreover, we see continued requests from the provinces for protection from maritime violence. An important example of this is found in a case from November 1752, when Panayiotis Yanakis, a ḳocabaşı (non-Muslim local notable) in Kalamata, presented a takrir to the Ottoman government complaining that the military commander of Morea, Halil Bey, had seized one hundred purses of his goods and sold his family and children to "the infidels of Mani." 82 The official declarations of the qadi of Tripolis confirmed that ten members of Panayotis's household were seized, together with his goods, by a certain villain (şakī) called Todoraki, son of Komandro of Mani. A summary of the case further noted:

Every year, a frigate captain is appointed to the coasts of Koroni, Kalamata, and Mani on the island of Morea with the taxes of Koroni, in order to protect it against infidel pirates. Whilst Halil Bey was collecting and passing

\footnotetext{
79 TNA/sP 97/33 James Porter to Newcastle (17 May 1747).

8 в вОА/С.BH.178/8372 (11 Muharrem 1156 / 8 March 1743); С.вн.83/3997 (13 Şevval 1156 / 30 November 1743).

81 вОА/С.вн.84/4036 (6 Rebiülevvel 1163 / 13 February 1750); Divan-ı Hümayun, Başmuhasebe Kalemı Defterleri (Imperial Council, Chief Accounting Office Registers, D.BşM.d.) 3080 (2 Cemaziülevvel 1163 / 9 April 1750); C.BH.25/1171 (2 Safer 1165 / 20 December 1751).

82 воА/С.ZB.72/3563 (18 Muharrem 1166 / 24 November 1752).
} 
the taxes of Koroni to one of his own men, the Nafplio frigate captain Deli Hüseyin, Deli Hüseyin's frigate, together with the pirate Todoraki son of Masko Komandro - who was continually engaging in piracy with the Maltese infidels - again levied the said taxes contrary to custom and, with the help of the aforementioned Halil Bey, engaged in piracy on the said coast. As this is dangerous to the security of the inhabitants of the province, the said pirate must by all means be seized wherever he be found, and punishment given. In this matter, the attorneys of these subjects officially request in their petition that an exalted command be sent to the governor of Morea. ${ }^{83}$

This case seems to be rather exceptional, but the implications are fascinating. First, it shows that Ottoman naval captains, as with their European counterparts, were still not averse to engaging in illicit corsairing for their own enrichment, alongside other forms of corruption such as double taxation. Second, it seems that despite the naval patrols, this part of the Mediterranean was considered sufficiently dangerous that tax collection required a warship for protection. Finally, the mechanism of complaint is similar to that employed by the victims of British privateering, so that Panayiotis went straight to the local qadi courts (via a vekill, an agent, as he was a non-Muslim) and received judgments in his favor. He then travelled to Istanbul to bring his complaint directly to the imperial government. The cumulative effect of complaints against such threats posed by pirates and corsairs in the Aegean led to an imperial command boosting muhăfaza missions in the Mediterranean in the spring of 1753 , and coastal defenses were strengthened. ${ }^{84}$

The dangers of European privateering returned with the outbreak of the Seven Years' War, which added to this undercurrent of local violence, with the first attack of a British ship against four French vessels containing the goods of Ottoman merchants recorded in the harbor of Milos (Değirmenlik) in November $1755 .{ }^{85}$ After 1756 , violence began to increase, leading the British government to issue an order preventing British ships from seizing Ottoman subjects or ships, taking any French ships out of Ottoman harbors, or seizing any French ships carrying Ottoman goods. ${ }^{86}$ Consequently, more care was taken than in the previous conflict, but numerous British privateers continued

83 Ibid.

84 BOA/C.BH.271/12511 (18 Cemaziülevvel 1166 / 24 March 1753); Cevdet Tasnifi, Maliye (Cevdet Series, Financial, c.ML.) 51/2372 (7 Rebiülahir 1167 / 31 January 1754).

85 вОА/C.HR.68/3384 (16 Safer 1169 / 21 November 1755).

86 TNA/sP 97/39 Copy of an Order of Council, 1 June 1756. 
to take prizes around ports and in Ottoman coastal waters. One petition submitted on behalf of the French ambassador in March 1757 complained of a British captain named Wilson cruising in and around the Aegean islands and the Gulf of Izmir, taking five French ships and selling them in Ottoman ports, whilst another in October saw a British privateer taking French and Ragusan ships under the guns of Foça. ${ }^{87}$ Aware of the risk such violence posed to their shipping and subjects, the Ottomans reissued the 1744 maritime regulations in April 1758, with the official Italian translation of the Ottoman command presented to the British ambassador James Porter stating that:

A straight line is to be imagined as the furthest border of the Ottoman Empire, running from the Morean peninsula and ending in the Gulf of Sirte in the southern end of the western part of Egypt, to the east of which the Sublime Porte desires that a regulation be made so that the ships of Britain and France will not harm each other in any way. ${ }^{88}$

The Ottoman state had therefore once again extended its maritime boundaries out into the Mediterranean Sea. On this occasion, the combination of the Ottoman maritime regulations backed up by pressure from the British authorities seems to have worked to some degree in restraining the British privateers, as there are far fewer recorded incidents of Ottoman merchants being attacked in the ways they were in the $1740 \mathrm{~s}$.

However, the experiences of the 1740 s had taught the Ottomans that relying on maritime regulations alone would not make their seas safe during this new conflict. This renewed threat by supposedly friendly nations required a physical presence to both deter privateer and corsair attacks and to reassure the local population. Fourteen imperial frigates were sent to protect the Mediterranean in $1758 / 9$, a level similar to that at the end of the previous conflict, and the imperial dockyards and the gunpowder factories in Gallipoli continued to provide the stores and armaments necessary for these missions, as well as certain rations and provisions. ${ }^{89}$ However, as with earlier missions, the state drew on provincial resources to help pay for the maintenance of such a large

87 воA/C.HR.154/7682 (6 Receb 1170 / 26 March 1757); вOA/C.HR.24/1186 (5 Safer 1171 / 19 October 1757). On Wilson, see: Eldem, “Strangers in their own seas?", 48-49.

$88 \mathrm{TNA} / \mathrm{sP}$ 97/40 Translation of a memorial or request of the Ottoman Porte (Italian), undated but in Porter's letters of 28 July 1758.

89 For example: BOA/С.BH.74/3504 (25 Cemaziülahir 1169 / 26 March 1756) for gunpowder; C.BH.199/9313 (16 Şevval 1174 / 21 May 1761) for provisions; C.BH.12/570 (11 Şevval 1175 / 6 May 1762) for lead shot. 
operational fleet, effectively directing provincial tax revenues to provide for provincial defense, so that 33,410 gurūş out of a total expense of 48,767 gurüş was taken as ocaklık from the Rhodes treasury and the funds of certain tax-farms..$^{90}$ This system, it must be said, did not always work as planned; a case reported in April 1769 revealed that funds due to the fleet as ocakllk from a levy on the income of the Aleppo horse market tax-farm had in fact been embezzled by the local military commander. ${ }^{91}$

Moreover, the impact of this shared burden was, it seems, not always appreciated by Istanbul. One petition sent to Mustafa III in July 1763 showed that certain provincial officials were obliged to take things further and help in the construction of ships engaged in muhäfaza. The petition, from 'Abdullah Re'is, Mehmed Re'is, and another Mehmed Re'is, all of Chania, narrates the problems that apparently arose from this duty:

As a consequence of piratical banditry taking place around our province, certain people of the island provided a frigate and a pergende with their own finances to protect [the island] from pirates. A few years ago, as a result of reports of certain müste'min nations acting irregularly, an exalted command was sent forth saying 'you must construct a frigate and a pregende, and go out to sea to protect [the island] against pirates.' As the pirates found an opportunity to commit harm against the servants of God around Crete, and as a result of the mercies from the imperial household of the World-Holder commanding compassion towards the people of Islam, we, your slaves, built our pergendes with our own funds, equipping them with what was required at the time. Now that this work is completed, it is requested that a resplendent imperial order be commanded to the governors of Crete so that certain weapons of war be provided by the Chania armoury should [this service] be required from this region again. ${ }^{92}$

Thus, despite all of the effort that was put into asserting central authority by patrolling the Mediterranean and reinstituting the maritime regulations in order to control the European privateers and other corsairs and pirates, the state relied on local naval commanders building and equipping new ships at their own expense.

\footnotetext{
90 вОА/С.BH.199/9315 (17 Rebiülahir 1171 / 29 December 1757).

91 BOA/C.ML.631/25924 (23 Zilhicce 1182 / 30 April 1769).

92 BOA/C.BH.104/5011 (2 Muharrem 1177 / 13 July 1763).
} 
The need to rely on the provinces to contribute to the fleet can be explained by the greatly increased level of naval operations during the Seven Years' War. Yet this exposes an underlying frailty of the Ottoman naval response due to the scale of operations and the resources required to support them. This is particularly significant when we consider the official rationale behind such missions in the following imperial command issued in September 1758:

For protection and security from the schemes and violence of the banditry of pirates against the merchants, müste'min nations, and especially against the galleons and three-mast ships coming and going to Egypt in the waters of my Well-Protected Domains in the Mediterranean, for the protection and security of the servants of God residing in the islands and on the coasts from injustice and attack, and for the needs and requirements of their security and ease in the procurement of goods, the galleons of the imperial fleet and warships of the naval commanders are to go into the Mediterranean in the summer season for the swift accomplishment of these goals. In communicating to you, vizier, of the need to patrol around the islands and other waters of my Sublime State due to the reports sent forth by Muslim judges of the seizures and damages of the groups of brigands [committing] piratical banditry, this blessed year the galleons and warships of the imperial fleet are to be organized and equipped again in accordance with previous practice to be assigned and appointed to the protection of the Mediterranean Sea. ${ }^{93}$

The idea of muhăfaza was not simply rhetorical. The Ottoman state was intent on keeping its waters open for the commerce of Ottoman subjects and foreigners, and on protecting Ottoman subjects ( 'ibädullah, lit. servants of God) from all maritime violence. The emphasis on maintaining the routes between Egypt and the wider Ottoman realms is linked to the protection of movement in the open sea, and to the maintenance of the all-important grain shipments. With famine once again prevalent in Palestine and Syria, it was essential for the state to ensure the movement of provisions. ${ }^{94}$ For instance, in 1755 a command made out of concern for the welfare (refäh) of Muslim subjects forbade both

93 BOA/С.BH.254/11749 (1 Muharrem 1172 / 5 September 1758). For a discussion of ocaḳlık, see: Michael Robert Hickok, Ottoman Military Administration in Eighteenth-Century Bosnia (Leiden, 1997), 42-53; Charles Wilkins, Forging Urban Solidarities: Ottoman Aleppo, 16401700 (Leiden, 2010), 141-157. 
harbì (enemy) and müste'min European merchants from purchasing grain. ${ }^{95}$ The command for the Cretan naval commanders to build their own ships was also phrased in terms of protecting the vulnerable Muslim subjects of that island. Yet, there is a disconnect between the rhetoric of imperial protection illustrated by the dispatch of fourteen galleons to protect Ottoman waters and subjects and a command that ordered local notables to build their own ships for their own protection. Clearly, the Ottoman fleet, however large, could not be everywhere all the time, and thus some degree of localization of defense was required. Such logistical issues did not, however, hinder the wider effort.

Despite all these measures, the Ottoman Mediterranean, as with the Mediterranean in general, continued to suffer from violence during the Seven Years' War. Sometimes there were successes, such as the pirate ship captured in 1758 , with four enslaved Ottoman Greeks liberated and 27 "infidel pirates" enslaved. ${ }^{96}$ On the whole, however, coastal defenses were still under pressure, with pirate attacks around Nafplio leading the governor of Morea to petition for measures to improve the security of the castle there, and on Rhodes it was deemed necessary to increase the number of shore-watchmen. ${ }^{97}$ Moreover, as late as the summer of 1761 , the Ottoman state was receiving complaints from the French ambassador that British privateers were attacking their ships around Bodrum and Egypt. ${ }^{98}$ Nonetheless, the level of European violence against Ottoman subjects and shipping was at a lower level than had been the case during the conflict of the 1740 s, and far fewer complaints were made against British privateers by Ottoman merchants. In the face of continued corsair and pirate attacks in the Morea and Aegean islands, as well as the threat of European privateers, the Ottoman policy of muhăfaza aiming to protect trade, secure the grain routes, and defend the littoral population by enlarging the fleet, reinstituting the maritime regulations, and sharing the burden of expense with the provinces had had some effect. However, even these combined defensive measures could not stop attacks from occurring altogether.

\footnotetext{
95 вOA, Cevdet Tasnifi, İktisat (Cevdet Series, Economic, C.їктs.) 34/1653 (15 Zilhicce 1168 / 22 September 1755).

96 воA/С.вн.273/12597 (25 Cemaziülahir 1171 / 6 March 1758).

97 вОA/C.ML.561/23026 (24 Ramazan 1173 / 10 May 1760); С.ZB.3/116 (6 Muharrem 1173 / 29 August 1759).

98 BOA/C.HR.93/4608 (9 Zilhicce 1174 / 12 July 1761).
} 


\section{Violence in the Mediterranean before the Ottoman-Russian War,} 1764-177o

Muhăfaza missions continued in the aftermath of the Seven Years' War, initially on a smaller scale, as the baseline threat of corsairs and pirates remained. ${ }^{99}$ In October 1765 a complaint was received from Morea of attacks taking place on the coast near Basova (Passava), where pirate ships had been seizing and enslaving Muslims. This petition, initiated by the pleas for help of the inhabitants and qadi of the Mistra district, led to the garrison at Basova being strengthened with additional troops for the area's protection and security (hifz ve hiräset) ${ }^{100} \mathrm{~A}$ few years later, a command was issued describing attacks on merchant shipping off the coasts of Cyprus and Syria, and in the seas around Damietta, ordering the admiral take action by dispatching an imperial galleon and one or two frigates "for the protection and security of the waters of my Sublime State."101 In this case, the culprits were identified as two Spanish frigates and a patrol ship, evidence of the low-level conflict between Spain and the Ottomans prior to the granting of Capitulations to the Spanish in $1782 .{ }^{102}$

The identity of many of the non-müste'min corsairs being chased around the Mediterranean has remained largely absent from the documents examined, except for the usual description of "infidel" (kefere). One document from 1767 opens up details of the captures made by a group of ships sent to guard the Mediterranean. ${ }^{103}$ It is a list of slaves seized and captured from four different korșan ships: first, thirty sailors taken by pergende captain el-Hac Cafer Bey from a galleon in the Mediterranean, made up of twenty-three Maltese, two French, two Neapolitans, a Venetian, a Spaniard, and one unknown; second, a Venetian and an Austrian taken from a ship in the Aegean islands by frigate captain İbrahim Bey; third, a crew comprising three Neapolitans, two Maltese, and two from Spetses (Suluca); and fourth, six korsans from Kalamata taken from a scampavia by frigate captain 'Ali. The first ship, having a majority crew of Maltese, alongside a smattering of other Europeans, can reasonably be labelled a Maltese corsair. The identity of the second is unclear, as is that of the

\footnotetext{
99 BOA/C.BH.242/11218 (17 Receb 1177 / 21 January 1764); C.BH.194/9121 (20 Şevval 1178 / 11 April 1765).

100 вОА/С.Zв.40/1999 (2 Cemaziülevvel 1179 / 17 October 1765).

101 BOA/C.BH.183/8582 (end of Zilhicce 1180 / 28 May 1767).

102 On the Ottoman-Spanish conflict: Eloy Martin Corrales, "Greek-Ottoman Captains in the Service of Spanish Commerce in the Late Eighteenth Century" in Trade and Cultural Exchange, 203-222.

103 вОА/С.BH.8/367 (25 Cemaziülahir 1181 / 17 November 1767).
} 
third, although it is notable that aside from the two captives from the Ottoman island of Spetses they were all müste'min. The fourth ship was undoubtedly a Maniot pirate, with all the captives being from the port of Kalamata, and, according to another record, the capture being made off the coast of Mani. ${ }^{104}$ The Ottoman state therefore faced continued threats from pirates and corsairs of Maltese, Spanish, müstemin, and Ottoman origin in the mid-176os. It is in this context that the imperial command of September $175^{8}$ was reissued in 1766 with the aim of ensuring the free movement of merchants and the protection of Ottoman ports and coastal settlements from attack. ${ }^{105}$ This was confirmation of the seriousness of the situation, further emphasized by the fact that nine galleons holding almost 3,00o levends were sent annually on muhăfaza missions on rotation in the winter and summer seasons, requiring significant provisioning and financing. ${ }^{106}$

On the eve of the outbreak of war with Russia in 1768 , a significant force of eight imperial galleons came to Istanbul to be re-equipped by the imperial arsenal for their next muhăfaza mission, having already served one tour in the Mediterranean. ${ }^{107}$ Three further ships were still out on patrol, making a total of eleven galleons; this does not support the notion that the Ottoman fleet had backed away from the Mediterranean in this period. With the impending approach of the Russian fleet following the formal outbreak of war in October, such muhäfaza missions must have taken on a different sense of purpose. The Ottoman fleet that would face up to the Russians - who had received significant logistical assistance from the British en route to the Mediterranean from the Baltic - was a battle-ready force with decades of experience pursuing various sorts of enemies in the defense of Ottoman waters. At the same time, having been employed largely in anti-piracy missions, it had been some decades since the Ottoman navy in the Mediterranean had engaged in naval warfare against the fleet of another state.

The first year or so of the war saw no direct confrontation, and the business of guarding the Mediterranean continued. Huge resources were placed into muhăfaza going into 1769 , with no less than seventeen imperial

\footnotetext{
104 BOA/C.BH.273/12591 (2 Zilhicce 1181 / 19 April 1768). See: Gelina Harlaftis, A History of Greek-Owned Shipping: The Making of an International Tramp Fleet, 1830 to the Present Day (London/New York, 1996), 4.

105 вОА/С.Bн.13/627 (15 Sevval 1179 / 26 March 1766).

106 воA/С.вн.15/718 (18 Ramazan 1179 / 28 February 1766). See also: C.вн.13/650 (7 Zilhicce 1179 / 16 May 1766); C.вн.257/11906 (19 Muharrem 1180 / 27 June 1766); C.вH.257/119o9 (10 Şevval 1180 / 11 March 1767); C.BH.209/9781 (8 Cemaziülevvel 1182 / 20 September 1768). 107 вОА/С.BH.180/8453 (7 Zilkade 1181 / 26 March 1768).
} 
frigates assigned for that task, with $29,716 \dot{g} u r u \bar{s} s$ of their salaries paid as ocakllk from the Rhodes treasury and tax-farms, the remaining 27,083 gurusş coming from the imperial treasury. ${ }^{108}$ In November 1769 , the galleon of Kassabcı el-Hac 'Ali and the pergende of Sakızlı Hüsseyin were appointed for muhăfaza in spring and, being provided with the usual rations of brown rice, lentils, olive oil, and hard-tack from the imperial stores, went out with the galleon $\dot{G} a z \bar{a} l-\iota$ Bahrī (The Gazelle of the Sea) to patrol around Rhodes to gather intelligence on and defend against pirates there. ${ }^{109}$ Elsewhere, the imperial frigates appointed to protect Morea seized a pirate scampavia and enslaved the twenty-four crewmembers in March $1770 .{ }^{110}$

However, in the summer of 1770 , the Russians arrived in the Mediterranean in strength. At the Battle of Çeşme, fought between July 5 and 7 , the Ottoman fleet was destroyed in a raging fire sparked during combat. Despite this catastrophe, Ottoman naval efforts to protect the Mediterranean did not collapse. Just a few weeks after the battle, on July 24,1770 , commands were issued for the provisioning of seven merchant ships with a combined total of 11.5 kantars of lead shot and 130 kanțars of black powder to perform muhăfaza duties in the Mediterranean. ${ }^{111}$ This step of resorting to privateering ships to provide the protection for Ottoman coasts and islands demonstrates the losses that the navy faced in the immediate aftermath of Çeşme but also that the Ottomans were capable of organizing this under extreme pressure. By the next spring, muhăfaza measures seem to have begun to return to normal, with the dispatch of two imperial galleons to the Mediterranean in March 1771, as well as serious efforts undertaken to strengthen the garrisons and fortifications on vulnerable islands such as Patmos. ${ }^{112}$ We still find the ranks of the Ottoman navy being bolstered by merchant ships acting as privateers, with seven accompanying the Nașr-ı Bahri into the Mediterranean in the spring of $1771 .^{113}$ However, despite the damage done to the Mediterranean fleet at Çeşme, efforts still continued to protect Ottoman subjects from the ongoing threat of corsairs and pirates. Viewed from this perspective, the disaster in 1770 was far less drastic on the

\footnotetext{
108 воA, Ali Emiri Tasnifi, III. Mustafa (Ali Emiri Series, Mustafa III, Ae.Smst.ıII.) 2/86 (14 Zilhicce 1183 / 11 April 1770).

109 воА/С.вH.13/638 (19 Receb 1183 / 18 November 1769); с.вH.16/794 (1 Şaban 1183 / 30 November 1769$)$.

110 BOA/C.BH.14/670 (23 Zilkade 1183 / 21 March 1770).

111 BОА/С.вн.204/9561 (1 Rebiülahir 1184 / 24 July 1770).

112 вОA/С.BH.219/10176 (2 Zilhicce 1184 / 19 March 1771); Cevdet Tasnifi, Askeriye (Cevdet Series, Military, C.AS.) 56/2617 (end of Zilkade 1184 / mid-March 1771).

113 вОА/С.BH.204/9563 (18 Zilhicce 1184 / 4 April 1771).
} 
ground that it was in the outpouring of reflection it engendered in its wake through the pens of Ottoman elites. ${ }^{114}$

We might, however, see Çeşme, as the symbolic start of a new sort of Northern Invasion, with a gradual shift towards territorial encroachment on Ottoman lands and seas, first by the Russians, then by the French, and later the British. From this perspective, the list of Ottoman naval defeats noted at the beginning of this article-Ceşme, Gerontas, Navarino, Sinop-are less indicators of decline than of a new period of northern domination through violence that began to be displayed during the European privateering wars of the later seventeenth and eighteenth centuries. Although there are reports of Ottoman ships being seized by Maltese pirates into the 1780 s, their threat was greatly diminished and would soon be altogether removed. ${ }^{115}$ After 1770, the dispatch of Ottoman troops to Mani in response to a revolt catalyzed by the Russian invasion saw a significant attempt to reduce piracy from the Morea, and, as the research of Gelina Harlaftis and Sophia Laiou has shown, from that period Greek and other Ottoman shipping began to play an increasingly important part in the Mediterranean economy, in part due to the seemingly interminable inter-European conflicts brought first by the war in North America and then by the French Revolution. ${ }^{116}$ Zooming back from this macro vision of events, however, to Nașr-ı Bahrī setting off from Istanbul in 1771 with cannonballs and gunpowder taken from the imperial arsenal to protect the Mediterranean once again, we are reminded that 1770 did not mark the end of Ottoman attempts to protect its waters.

\section{Conclusions}

After the war with Russia, muhäfaza missions resumed at pre-war levels with between eight and ten galleons dispatched to the Mediterranean annu-

114 Virginia Aksan, “Ottoman Political Writing, 1768-1808," International Journal of Middle East Studies 25 (1993): 53-69.

115 For example, BOA/C.BH.59/276o (12 Rebiülevvel 1200 / 13 January 1786).

116 Gelina Harlaftis, “The 'Eastern Invasion': Greeks in Mediterranean Trade and Shipping in the Eighteenth and Early Nineteenth Centuries" in Trade and Cultural Exchange, 223-252, esp. 235-241; Gelina Harlaftis and Sophia Laiou, "Ottoman State Policy in Mediterranean Trade and Shipping, c.1780-1820: The rise of the Greek-owned Ottoman merchant fleet" in Networks of Power in Modern Greece: Essays in Honour of John Campbell, ed. Mark Mazower (London, 2008), 1-44. 
ally between the summers of 1774 and $1779 .{ }^{117}$ By that time, the Ottoman Mediterranean was once again threatened by European privateers, as the British and French returned in force due to the conflict in North America, and the maritime regulations were brought back in an attempt to halt violence against Ottoman shipping and subjects. ${ }^{118}$ Once again, British privateers and warships committed grave attacks against Ottoman merchants and pilgrims, which, in the aftermath of British logistical support for the Russian navy prior to Çeşme, severely strained British-Ottoman relations. Older threats also remained as evidenced by the Maltese corsair ship captured in 1779 with fourteen slaves taken and the Maniot pirate ship seized by the forces of Ahmed Paşa (al-Jazzar), the governor of northern Palestine, with fifty-three slaves sent to Istanbul in 1780.119

At the beginning of the 1780 s, therefore, many of the same problems that had troubled the Ottomans in the Mediterranean at the beginning of the $1720 \mathrm{~s}$ remained. The Aegean Islands, the coasts of the Levantine provinces, and Ottoman ships and goods on the open sea were still vulnerable to attack from Maltese corsairs, Morean pirates, or, during inter-European conflict, British and French privateers. In assessing the success of Ottoman efforts to protect the Mediterranean through muhăfaza patrols by the imperial fleet, it would seem that there is little positive to say. Yet, Ottoman attempts to use the navy to secure the safety of Ottoman trade and littoral populations reveal a number of important aspects of the relationship between the central authorities in Istanbul and local notables, commanders, judges, and subjects in the provinces. Whilst many of the salaries of the ships' crew and commanders was paid through ocaklı. using resources in provincial treasuries and tax-farms, the lion's share of provisions, munitions, and payments came from the imperial treasury, dockyard, armory, arsenal, kitchen, and customs house. The investment of the Ottoman state in protecting the islands and coasts of the Mediterranean saw a huge amount of money, food, and arms directed to the imperial fleet. At the same time, the state was able to rely on local notables and merchants to provide ships for muhäfaza service. This intertwined relationship between the center and the provinces was given a further, deeper layer of dependency,

\footnotetext{
117 воА/С.вн.62/2916 (27 Ramazan 1188 / 1 December 1774); С.вн.152/7261 (7 Safer 1190 / 28 March 1776); C.вH.225/11810 (23 Safer 1191 / 2 April 1777) с.вн.68/3327 (22 Rebiülahir 1193 / 9 May 1779).

118 BOA/C.HR.118/5877 (20 Safer 1193 / 9 March 1779).

119 воА/С.вн.199/9329 (17 Rebiülevvel 1193 / 5 April 1779); C.As.949/41175 (end of Zilhicce 1193 / beginning of January 1780).
} 
as witnessed in the complaints, petitions, and pleas for assistance from local authorities and merchants for protection from seaborne violence. ${ }^{120}$

The documentary evidence from the workings of the Ottoman state show the construction of this strategy of regular naval patrols and evolving legislation from the late seventeenth century and particularly in the aftermath of Passarowitz, becoming a firm and regular feature of Ottoman efforts by the 1740s, and showing the defeat at Çeşme in 1770 not as a breaking point but as a setback from which the patterns established soon recovered and resumed. As well as showing that the problems the Ottoman state faced at sea at the end of the 1710 s were still present by the end of the 1770 s, this period also demonstrates the persistence of the Ottoman response to the eighteenth-century manifestation of the Northern Invasion, as well as other endemic threats from the wider Mediterranean, through these developing structuresand practices of protection. The growing investment in muhäfaza patrols from the late 173os was a legacy of earlier conflicts with the Venetians and Habsburgs in seeking to actively define maritime space, as well as a response to ongoing corsair attacks. However, one of the driving factors was the huge amount of violence perpetrated by müste'min privateers during the War of the Austrian Succession and Seven Years' War. In the almost thirty years between the Treaty of Belgrade in 1739 and the outbreak of war with Russia at the end of 1768 , the Ottoman Mediterranean was subjected to fifteen years of violence committed by European privateers. This led to the solidification of the maritime regulations as a legal means to prosecute European attacks that affected Ottoman shipping through the imperial commands of 1744 and $175^{8}$, as well the strengthening of fortifications and garrison strength in island and coastal defenses. But it was the regular presence of the imperial fleet that provided a visible Ottoman response to these bursts of European privateering, as well to more endemic maritime threats.

This analysis of protective naval missions in the mid-eighteenth century therefore reveals a considered - if not entirely successful - attempt by the Ottoman state to assert maritime territoriality in the Mediterranean through the regular presence of imperial ships patrolling the islands and coastal waters, as well as the wider sea, to protect shipping and settlements from attack. This was due to a combination of a number of factors: developing notions of territoriality following the treaties of Carlowitz, Passarowitz, and Belgrade; petitions

120 In some ways, this mirrors Ottoman attempts to secure authority in the provinces in the sixteenth century, creating a balance of dependency between the imperial center and provincial centers. See: Emrah Safa Gürkan, "The Centre and the Frontier: Ottoman Cooperation with the North African Corsairs in the Sixteenth Century," Turkish Historical Review 1 (2010): 125-163, especially 156-160. 
for assistance from the provinces; a need to maintain the passage of food staples at a time of frequent shortages; and ongoing threats to trade from a number of internal and external parties. The significant investment of ships, men, and supplies in this attempt to guard and protect the Mediterranean shows that the Ottoman state took the job of muhäfaza seriously, and that the Ottoman navy was far from an impotent force in the eighteenth century. The evidence of legal and military measures coming from the Ottoman authorities challenges the idea that the Ottoman state retreated from the end of the sixteenth century, and that it was unwilling and/or incapable of defensive action so that, to quote Eldem, it "abandon[ed the Mediterranean] to the interaction-and conflicts - of those who had either the means or the need to fill in the vacuum it had created: fledgling pirates, local navigators under the growing threat of foreign competition, and, of course, French and other western navies which were gradually taking control of this no man's land."121 Ottoman patrols in the Mediterranean, as well as the extraordinary legal measures of the maritime regulations, indicate to the contrary that there was no retreat or abandonment but rather an increasing investment of money, stores, and diplomacy into protecting Ottoman littoral space and maritime trade that even the disaster at Çeşme failed to hinder. Further comparative research within and without the Ottoman realms needs to be undertaken to better understand the Ottoman relationship with its waters in this crucial period. But for now, the notion of muhăfaza in the eighteenth century Mediterranean shows that Ottoman maritime space and Ottoman maritime policies played a key role in cementing evolving notions of imperial sovereignty and territoriality, in maintaining center-provincial interactions, and in regulating Ottoman-European relations.

121 Greene, Catholic Pirates, 5; Eldem, "Strangers," 52. 